\title{
Optimizing tax revenue in Indonesia during the COVID- 19 pandemic and how to implement the new VAT rate in Indonesia
}

\author{
Calvin Hadi, Carlos Barreto \\ DOI: 10.29322/IJSRP.11.11.2021.p11939 \\ http://dx.doi.org/10.29322/IJSRP.11.11.2021.p11939
}

\section{BACKGROUND}

$\mathrm{O}_{\mathrm{P}}^{\mathrm{n}}$ ne of the goals of the Republic of Indonesia based on Pancasila and the 1945 Constitution is to promote the general welfare for the sake of social justice for all Indonesian people. In an effort to realize this goal, the Republic of Indonesia needs to manage state finances which are realized in the form of the State Revenue and Expenditure Budget (APBN) which is a reflection of state finances. One of the sources of state revenue included in the state budget is taxes. Taxes are a way for the community to synergize with the state in accelerating the development of various sectors, including security facilities needed by the community. Article 23A of the Constitution of the Republic of Indonesia stipulates that taxes and other levies of a coercive nature for the purposes of the state are regulated by law.

The countercyclical fiscal policy implemented by the government during this pandemic requires optimal state revenue support. Tax revenues, excluding excise, import and export duties, are still the main pillar of state revenue with a contribution of around $41.3 \%$ of the total State Revenue and Expenditure Budget (APBN). Is the condition of economic growth in the first quarter of 2021 still contracting $0.74 \%$ and the implementation of tax reform, can be the hope of optimizing tax revenue in the midst of the current economic recession? In the 2021 State Budget Financial Note, it is stated that amid the uncertainty due to the Covid-19 pandemic, support for the business world is absolutely necessary to mitigate the economic impacts that arise and encourage the acceleration of national economic recovery.

In the field of state revenues, the Government is formulating tax reforms for 2021-2024 with two main objectives. First, to encourage national economic growth through targeted incentives and reducing business burdens. Second, optimizing state revenues by adding new tax objects and subjects, increasing taxpayer compliance and improving governance and administration.

From the data on the realization of the 2020 State Budget, the realization of tax revenues was recorded at Rp. 1,072.1 trillion or a $19.6 \%$ contraction compared to the realization in 2019 . This realization was $89.4 \%$ of the APBN target from Perpres 72 or there was a shortfall of around Rp. 126.7 trillion. The shortfall factor contributed to the swelling realization of budget financing by Rp945.8 trillion or an increase in the budget deficit to $6.1 \%$ of Gross Domestic Product (GDP). Another factor is the handling of the Covid-19 pandemic and economic recovery which requires large costs.

This publication is licensed under Creative Commons Attribution CC BY.

http://dx.doi.org/10.29322/IJSRP.11.11.2021.p11939
If you look at the largest tax accounts, the realization of Income Tax $(\mathrm{PPh})$ in 2020 reached Rp594 trillion or a $23.1 \%$ contraction compared to the realization in 2019. With the achievement of only $88.6 \%$ of the 2020 target. This condition came from Corporate Income Tax which contracted quite deeply due to several factors. First, the slowdown in the profitability of business entities in 2019 as the basis for calculating the 2020 tax. Second, tax incentives in the form of installment discounts of $30 \%$ to $50 \%$. Third, the reduction in corporate income tax rates from $25 \%$ to $22 \%$.

Furthermore, the realization of Value Added Tax and Luxury Goods Sales Tax (PPN and PPnBM) amounted to Rp.450.3 trillion or contracted by $15.3 \%$. This was mainly from Domestic VAT and Import VAT, which contracted quite deeply due to the decline in domestic consumption amidst conditions of social restrictions and accelerated restitution incentive policies. It should be noted, in general, that the decline in tax revenues was due to the use of tax incentives, which contributed around $22.1 \%$ to the decline in the realization of tax revenues in 2020.

Meanwhile, in the 2021 State Budget, tax revenues are targeted at Rp1,229.6 trillion or $14.7 \%$ higher than the realization of tax revenues in 2020. With details, PPh is targeted at Rp638 trillion or $15.1 \%$ higher than the realization in 2020. and PPN and PPnBM are targeted at Rp518.5 trillion or $15.1 \%$ higher than the realization in 2020.

With such a large target, tax revenues will contribute $44.7 \%$ of the total 2021 APBN. The target is sufficient to support the need for spending to handle the pandemic and support the national economic recovery program. However, with the basis of economic growth in 2020 minus (-) 2.07 percent and the first quarter of 2021 still contracting $0.74 \%$, the 2021 tax revenue target will be quite heavy.

To measure this, as an initial indication, it is necessary to look at the realization of tax revenues until April 30, 2021. Realized tax revenues amounted to Rp. 374.9 trillion or a contraction of $0.46 \%$ compared to last year. This realization is better than the same period in 2020 which contracted $3.01 \%$. In detail, the realization of Non-Oil and Gas PPh amounted to Rp216.3 trillion or a contraction of $4.52 \%$ and PPN and PPnBM by $\mathrm{Rp} 137.5$ trillion or grew $3.56 \%$ compared to the realization in 2020. Furthermore, Land and Building Tax (PBB) and Other Taxes amounted to 3.9 trillion or growing $67.3 \%$ and oil and gas $\mathrm{PPh}$ realized Rp17.2 trillion or grew $14.9 \%$ compared to the same period last year.

The non-oil and gas $\mathrm{PPh}$ contraction that was quite deep was due to, among other things, the combined effect of the economic 
slowdown, incentives to reduce $\mathrm{PPh}$ Article 25 installments by $50 \%$, lower corporate income tax rates to $22 \%$ and increase tax refunds. On the other hand, the positive growth of PPN and PPnBM shows a positive signal of recovery in public consumption and is supported by the momentum of the holy month of Ramadan and Eid al-Fitr.

Meanwhile, the performance of tax revenue in April 2021 was very good, especially Corporate Income Tax and Import VAT. This achievement was supported by the soaring performance of corporate income tax due to the decline in tax credits due to the use of fiscal incentives for exemption from import PPh 22 and reduction in PPh installments for the previous 25 years, as well as growing import activity.

On the other hand, taxpayer compliance in submitting the Annual Income Tax Return has increased significantly. The realization of annual SPT reporting as of April 30, 2021 was $12,248,158$ SPT or $12.8 \%$ higher than the same period last year. In detail, the annual tax return for corporate taxpayers increased by $26.8 \%$ and individual taxpayers increased $11.8 \%$. From the tax revenue data, several things can be concluded. First, in general, public consumption is still depressed where household consumption is still weak. Second, economic activity is starting to move, which can be seen from increased monthly mobility. Third, the tax revenue target for 2021 is quite heavy and has the potential for a shortfall.

Fourth, corporate income tax is estimated to continue to contract due to the contraction of economic growth in 2020, which is the basis for calculating corporate profits. Fifth, PPN and PPnBM are on a positive trend in line with the recovery in public consumption and the economy is turning again, even though it is running slowly.

In the Press Conference on APBN Kita on May 25, 2021, the Minister of Finance reiterated that the Government remains committed to continuing to provide tax incentives for affected sectors in 2021, especially MSMEs to encourage business activity and accelerate national economic recovery. The consistent and disciplined handling of the Covid-19 pandemic as well as the acceleration of the implementation of national vaccinations are still the main keys to the national economic recovery.

The government continues to make the best efforts in optimizing state revenues. However, if the estimated realization of state revenues does not meet the target, referring to Article 28 of Law Number 9 of 2020 concerning APBN for Fiscal Year 2021, the Government may use excess Budget Remaining (SAL) funds, withdraw cash loans, additional issuance of State Securities (SBN). , utilization of the cash balance of the Public Service Agency (BLU) and/or adjustment of state spending.

Currently, tax policies that have the potential to increase the burden on the community and the business world must be considered more carefully, including an analysis of their costs and benefits. The tax authorities' hard efforts in optimizing tax revenues should be appreciated. However, considering current conditions, intensification efforts should take precedence over extensification. Lastly, the implementation of countercyclical fiscal policy, without optimal state revenue support, will result in increased debt risk. The state budget deficit, which is projected at $5.7 \%$ in the 2021 State Budget, is not expected to widen.

Based on the background that has been explained, we have found the formulation of the problem, as follows: How to optimize tax revenue in Indonesia during the COVID-19 pandemic and how to implement the new VAT rate in Indonesia

\section{Discussion implementation of the new VAT rate in Indonesia}

The government is pushing for APBN reform to support structural reforms. One of them is in the field of state revenue through the ratification of the Law (UU) on the Harmonization of Tax Regulations (HPP).Among the various important issues in it, the HPP Law reforms the Value Added Tax (VAT) system. The Director General (Dirjen) of Taxes at the Ministry of Finance (Kemenkeu) Suryo Utomo said that the main points of the changes in VAT in the HPP Law were, among others, first, expanding the VAT base through refocusing on VAT exemptions and facilities, second, increasing VAT rates in stages, and thirdly applying the final VAT. . Furthermore, Suryo said that the expansion of the VAT base through refocusing on exemptions and VAT facilities was aimed at making VAT facilities more equitable and on target. In the HPP Law, the expansion of the VAT base for optimizing state revenues still takes into account the principles of justice and expediency. Especially in advancing the general welfare and the principle of national interest. This is in line with the principles of fair taxation and legal certainty. According to Suryo, Indonesia's opportunity to realize the vision of becoming a developed country in 2045 is very wide open if it is able to capitalize on the direction of changes in the demographic structure that is quite profitable at this time. This is indicated by the relative dominance of the productive age group and the decline in population dependency. In addition, the growth of the middle class group with a fairly large proportion of consumption is also a very important opportunity as a lever for economic growth. In this context, Suryo explained that the HPP Law was crucial to take advantage of the growth opportunities of the middle-class group. "The adjustment of the VAT regulation in the HPP Law actually also considers the opportunity for increasing public consumption which is driven by the growth of the middle-class group," said Suryo, Thursday (14/10). Meanwhile, Suryo said that taking into account the aspirations of the community, basic necessities that are needed by many people, health services, education services, social services, and several other types of services are provided with VAT exemption facilities. "Thus, even though they are taxable goods and services, people with low to middle income will still not pay VAT on the consumption of these goods and services as they are currently enjoying," he said. The Ministry of Finance noted that the VAT facility dominates tax expenditure (tax expenditure) every year. In 2020, VAT tax expenditures will reach Rp. 140.4 trillion or around $60 \%$ of the total tax expenditures of Rp. 234.9 trillion. As for Rp 40, 6 trillion came from the policy of exemption from VAT collection by small entrepreneurs (threshold VAT). Meanwhile, the VAT rate increase is carried out in stages, namely to $11 \%$ starting April 1, 2022 and to $12 \%$ no later than January 1, 2025. This is done by taking into account the improving economic conditions and optimizing state revenues while still realizing a fair taxation system. and legal certainty. Referring to the VAT rate of other countries, the VAT rate in Indonesia is relatively lower than the world average of $15.4 \%$. It is also lower than the Philippines (12\%), China (13\%), Saudi Arabia (15\%), Pakistan (17\%) and India $(18 \%)$. In addition, VAT collection will also be given to certain types of goods or services or certain business sectors through the application of the final VAT rate. For example $1 \%$, 
$2 \%$, or $3 \%$ of business turnover. This shows that the increase in VAT rates is carried out while taking into account aspects of administrative convenience as has been done by the government so far. "The government is also committed to strengthening various social assistance and other social protection programs to ensure the fulfillment of the basic needs of poor and vulnerable families. Such as for food, education and health as part of the acceleration of empowerment and poverty alleviation programs," said Suryo. The government is also committed to strengthening various social assistance and other social protection programs to ensure that the basic needs of poor and vulnerable families are met. Such as for food, education, and health as part of the acceleration of empowerment programs and poverty alleviation," said Suryo. The government is also committed to strengthening various social assistance and other social protection programs to ensure that the basic needs of poor and vulnerable families are met. Such as for food, education, and health as part of the acceleration of empowerment programs and poverty alleviation," said Suryo.

\section{optimizing tax revenue in Indonesia}

In an effort to achieve the tax revenue target in 2021, the Government is aware of the many challenges that must be faced, especially with the implementation of PPKM along with the increasing number of positive cases of Covid-19. The government is required to always try to see and take advantage of various opportunities to continue to improve itself by taking into account the latest economic developments. According to the Director of Extension, Services and Public Relations of the Directorate General of Taxes (DJP) Neilmaldrin Noor, the strategies for optimizing tax revenues for the second semester of 2021 include:

A. Continue to improve the digital-based service probis to facilitate and provide convenience for taxpayers, especially during the pandemic.
B. Carry out monitoring activities for Period Payments (PPM) to ensure that the period deposits of taxpayers are in accordance with economic conditions and carry out monitoring activities/Material Compliance Testing (PKM) utilizing data and information managed by DGT.

C. Expansion of the tax base, among others through the appointment of new collectors and supervision of the implementation of PMSE VAT collection. It can be informed that until July 21, as many as 55 PMSE collected VAT worth 2.64 trillion rupiah $(\mathrm{Rp} 1.9 \mathrm{~T}$ is a deposit in 2021)

D. The sectors that are prioritized in extracting potential in 2021, especially after PPKM are sectors that of course experience growth (dynamization) taking into account the potential for taxes and the ability of taxpayers to pay (ability to pay).

\section{REFERENCES}

[1] https://newssetup.kontan.co.id/news/cermati-tiga-policy-baru-ppn-di-uuharmonization-peraturan-perpajakan?page $=$ all

[2] https://www.kemenkeu.go.id/publikasi/article-dan-opini/menakarpenerimaan-pajak-di-tahun-pandemi/

[3] https://www.pajakonline.com/ini-strategi-optimalisasi-penerimaan-pajaksemester-ii-2021/

\section{AUTHORS}

First Author - Calvin Hadi

Second Author - Carlos Barreto 